International Journal of Engineering \& Technology, $7(2.24)(2018)$ 552-555
International Journal of Engineering \& Technology
SPC
Website: www.sciencepubco.com/index.php/IJET
Research paper

\title{
Experimental Study on Reactive Powder Concrete under Flexural Loading
}

\author{
Jeganmurugan $\mathbf{P}^{1 *}$, Rakesh Senthil Kumar $\mathbf{G} \mathbf{V}^{2}$, Sivasharmina $\mathbf{M}^{3}$, Sowmiya $\mathbf{S}^{4}$, Vasanthan $\mathbf{M}^{5}$ \\ ${ }^{1}$ Assisstant Professor, ${ }^{2} U G$ Student, ${ }^{3} U G$ Student, ${ }^{4} U G$ Student, ${ }^{5} U G$ Student, \\ Department of civil Engineering, Karpagam college of Engineering, Coimbatore. \\ *Corresponding Author Email: Jeganmurugan86@gmail.com
}

\begin{abstract}
Reactive powder concrete (RPC) is ultra high strength with advanced mechanical properties. Reactive powder concrete is a concrete without coarse aggregate, contains cement, silica fume, quartz sand, quartz powder, super plasticizer, steel fibre and polypropylene fibre with very low water cement ratio under normal curing condition. RPC has been produce with high compressive strength ranging from upto $800 \mathrm{MPa}$ with high flexural strength up to $50 \mathrm{MPa}$ and in some cases provided with absences of steel reinforcement. Mix proportions of RPC were found by trial and error method, the concrete cubes of size $100 \mathrm{mmx} 100 \mathrm{~mm} \times 100 \mathrm{~mm}$ were cast for find compressive strength of NRPC at 7days. Concrete cubes and cylinders of sizes $100 \mathrm{mmx} 100 \mathrm{mmx} 100 \mathrm{~mm}$ and $100 \mathrm{mmx} 150 \mathrm{~mm}$ have to be cast for finding compressive strength and split tensile strength at 28 days. Flexural strength of NRPC and MRPC will be find out by casting prism of size $500 \mathrm{mmx} 100 \mathrm{mmx} 100 \mathrm{~mm}$. The optimum mix proportion has to be finalized by comparing the results of all concrete specimens. Compressive strength test results shows that addition of silica fume upto $0.22 \%$ will increase the compressive strength of reactive powder concrete.
\end{abstract}

Keywords - Ordinary Portland cement, Silica fume, Steel fibres, Polypropylene fibres, Compressive strength, Flexural strength.

\section{Introduction}

Concrete is one of the necessary elements for structural work in the modern construction. The ultra high strength concrete (UHSC) has been developed in the recent years in concrete technology. RPC is a concrete without coarse aggregate but contains cement, silica fume, quartx sand, quartz powder and fibres with very low water cement ratio. [Richard and Cheyrezy, et.al, 1995].

The silica fume reacts with the calcium hydroxide, thus increasing the strength in the concrete and improves the bond between the cement and aggregate. Because of the pozzolanic property of the silica present in the silica fume reacts with the calcium hydroxide which forms during the hydration process of cement forms the CS-H gel. [Habel, et.al, 2006].

The production of RPC the optimum percentage of silica fume is found to be of $15 \%$ (by weight of cement). The quartz powder increases the compressive strength upto $10 \%$ when compared to the normal curing. RPC effectively suitable for prestressed applications. [Khadiranaikar.R.B, et.al, 2012]

The replacement of fly ash with cement increases the compressive strength and flexural strength. The optimum percentage of steel fibre used in the RPC has increases the superior mechanical properties and durability properties than the normal high strength concrete. RPC has an ultra high dense microstructure giving waterproofing and durability characteristics. [Dushmukh.A.R, et.al, 2016].

\section{Materials Used}

\section{A. Cement}

Dalmia, OPC 53 grade of cement is used in this project. The cement properties are determined to meet the requirements of IS 12269- 1987: Specification for 53 grade Ordinary Portland cement.

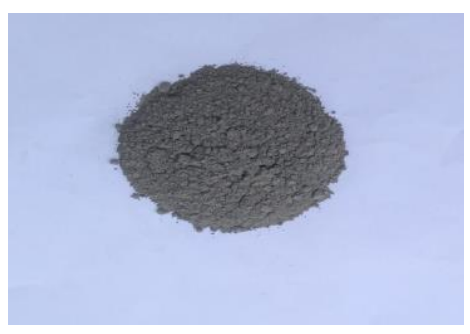

Fig.1: Cement

Table 1: Properties of Cement

\begin{tabular}{|c|c|c|}
\hline S.No & Property & Result \\
\hline 1. & Fineness & $98 \%$ \\
\hline 2. & Specific gravity & 3 \\
\hline 3. & Consistency & $26 \%$ \\
\hline 4. & Initial setting time & 35 minutes \\
\hline 5. & Final setting time & 255 minutes \\
\hline
\end{tabular}




\section{B. Silica fume}

The silica fume used in this experiment is extremely very fine particles which exists in grey colour powder form. The specific gravity is 2.4 and fineness is $86 \%$.

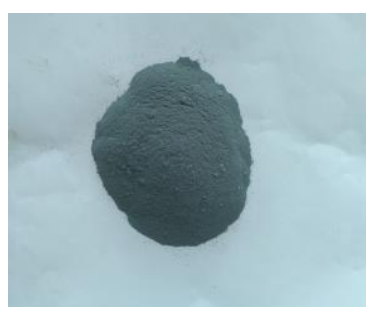

Fig.2: Silica fume

\section{Quartz sand}

The quartz sand used in this project was white high purity silica sand crystalline in nature and the particles size ranges from 450 to 600 microns. The specific gravity of quartz sand is 2.43 .

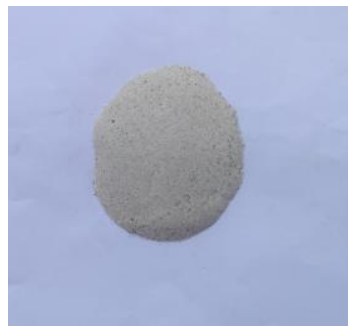

Fig.3: Quartz sand

\section{Quartz powder}

The quartz powder used in the project was white colour powder form and extremely very fine in nature. The specific gravity of quartz powder is 2.5 .

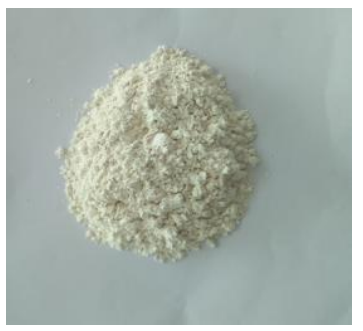

Fig.4: Quartz powder

\section{E. Water}

Water is a most important ingredient in concrete as it rises above certain limit it affects the water cement ratio and decreases the strength of the concrete. The $\mathrm{pH}$ value of the concrete is 6.5.

\section{F. Super plasticizer}

The RPC requires the very low water cement ratio can be only possible through the use of super plasticizer to achieve the required workability.

The Glenium 8233 formely B-233 which is reddish brown in colour and it is a poly-carboxylic ether based hyper super plasticizer.

\section{G. Steel fibre}

Hook end fibres used in this experiment which have diameter of $0.5 \mathrm{~mm}$ and length $30 \mathrm{~mm}$ and aspect ratio of 60 and procured from steel reinforcement redefined proceeded by Jeetmull Jaichandlall, Madras Pvt Ltd.

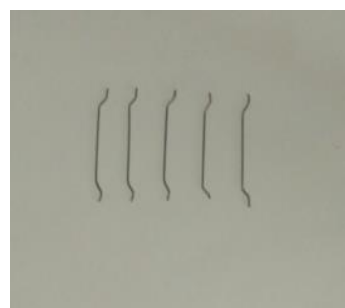

Fig.5 Steel fibre

\section{H. Polypropylene fibre}

The polypropylene fibre in this experiment which have the diameter of $0.0445 \mathrm{~mm}$ and length of $6.2 \mathrm{~mm}$ and aspect ratio of 139.33. The specific gravity of polypropylene fibre is 1.33 . The material was brought from suppliers, Coimbatore.

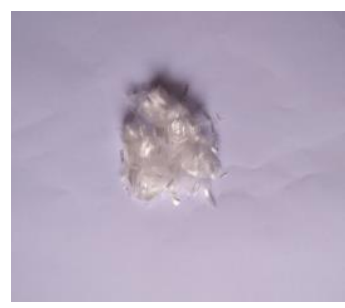

Fig.6: Polypropylene fibre

\section{Mix Proportion}

The mix proportion has been taken from the previous literatures guidelines. The mix proportion is based on the trial and error method.

Table 2: Mix Proportion for Normal RPC

\begin{tabular}{|c|l|l|c|c|c|c|c|}
\hline $\begin{array}{c}\text { S. } \\
\text { N }\end{array}$ & MP & $\mathbf{C}$ & SF & QS & QP & Water & SP \\
\hline 1 & MP1 & 1 & 0.22 & 1.2 & 0.5 & 0.4 & 3 \\
\hline 2 & MP2 & 1 & 0.24 & 1.2 & 0.5 & 0.4 & 3 \\
\hline 3 & MP3 & 1 & 0.26 & 1.2 & 0.5 & 0.4 & 3 \\
\hline
\end{tabular}

Thus the optimum mix ratio of concrete is 1:0.24:1.2:0.5

Table 3: For Modified RPC

\begin{tabular}{|c|c|c|c|c|c|c|c|c|c|}
\hline $\begin{array}{c}\text { S. } \\
\mathbf{N}\end{array}$ & MP & $\mathbf{C}$ & $\mathbf{S F}$ & $\mathbf{Q S}$ & $\mathbf{Q P}$ & $\mathbf{W}$ & $\mathbf{S}$ & $\mathbf{S F}$ & $\mathbf{P P}$ \\
$\mathbf{P}$ & $\mathbf{F}$ \\
\hline 1 & MP4 & 1 & 0.24 & 1.2 & 0.5 & 0.4 & 3 & 1 & 0.25 \\
\hline 2 & MP5 & 1 & 0.24 & 1.2 & 0.5 & 0.4 & 3 & 1 & 0.5 \\
\hline 3 & MP6 & 1 & 0.24 & 1.2 & 0.5 & 0.4 & 3 & 1 & 0.75 \\
\hline 4 & MP7 & 1 & 0.24 & 1.2 & 0.5 & 0.4 & 3 & 1.5 & 0.25 \\
\hline 5 & MP8 & 1 & 0.24 & 1.2 & 0.5 & 0.4 & 3 & 1.5 & 0.5 \\
\hline 6 & MP9 & 1 & 0.24 & 1.2 & 0.5 & 0.4 & 3 & 1.5 & 0.75 \\
\hline 7 & $\begin{array}{c}\text { MP1 } \\
0\end{array}$ & 1 & 0.24 & 1.2 & 0.5 & 0.4 & 3 & 2 & 0.25 \\
\hline 8 & $\begin{array}{c}\text { MP1 } \\
1\end{array}$ & 1 & 0.24 & 1.2 & 0.5 & 0.4 & 3 & 2 & 0.5 \\
\hline 9 & $\begin{array}{c}\text { MP1 } \\
2\end{array}$ & 1 & 0.24 & 1.2 & 0.5 & 0.4 & 3 & 2 & 0.75 \\
\hline
\end{tabular}

Thus optimum mix ratio of concrete is 1:0.24:1.2:0.5:1.5:0.5 


\section{Experimental Program}

\section{A. Compressive strength test}

The compressive strength test was carried out as per IS: $516-$ 1959. The compressive strength was determined by the cubes specimen of size $(100 \mathrm{~mm} \times 100 \mathrm{~mm} \times 100 \mathrm{~mm})$. The cubes specimen of size $(75 \mathrm{~mm} \times 75 \mathrm{~mm} \times 75 \mathrm{~mm})$ was also used. The required quantity of materials were weighed and then mixed the materials manually. The concrete was filled in the mould by four different layers and each layer was compacted well with help of tamping rod. The specimen was demoulded after 24 hours and adopted three different types of curing (a) cured in clean water for 7 days and 28 days, (b) Hot water curing for 7 days, (c) Hot water and Normal water curing for 7 days and 7 days. The specimens were taken out and wiped dry and then tested in compressive testing machine as per Indian Standard. The specimen was placed in such a way that the load acts opposite to the compacted surface of the specimen. The load was applied until the failure of the cubes. The ultimate load was noted. The compressive strength of the specimens were calculated and mentioned in the table. IV \& V

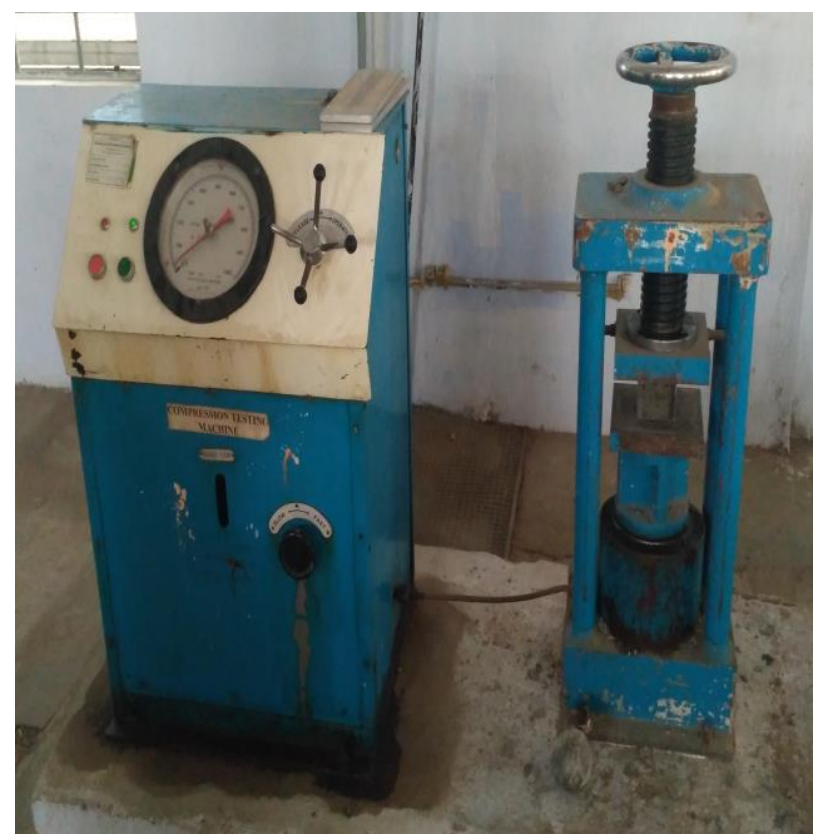

Fig.7: Compression testing machine

\section{B. Flexural strength test}

The prism of standard size $100 \times 100 \times 500 \mathrm{~mm}$ was used to determine the flexural strength of concrete. Three specimens were tested for 7 and 28 days. The required amount of material was weighed and the materials were mixed manually. The concrete was filled in the mould by four different layers and each layer was compacted well with help of tamping rod. The specimen was demoulded after 24 hours, cured in clean water for 7 days and 28 days of curing. The specimens were taken out and wiped dry and then tested in universal testing machine as per Indian Standard. Flexural strength is found using centre point loading system. The specimen is placed in the machine in such a manner that the load is applied to the uppermost surface as compacted in the mould. The axis of specimen is carefully placed with the axis of the loading device. Load is applied until the failure of the specimen. The ultimate load and breaking load is noted. The flexural strength of the specimens were calculated and listed in the table VII.

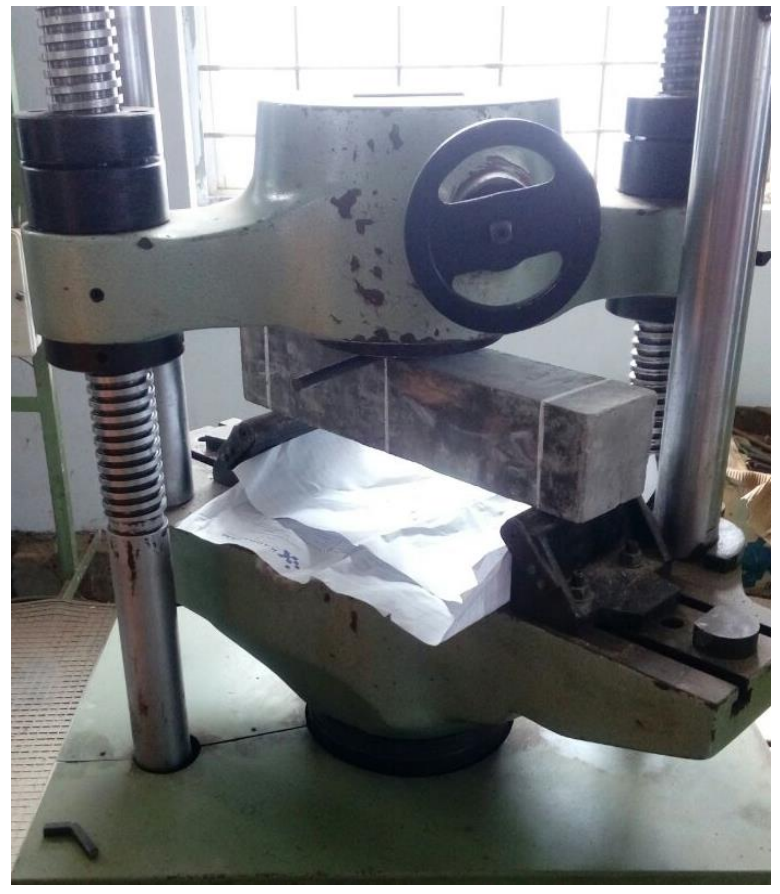

Fig.8: Universal testing machine

\section{Results And Discussions}

\section{Test Results}

Normal Curing

Table 4: For Normal RPC

\begin{tabular}{|c|c|c|c|}
\hline \multirow{2}{*}{ MP } & \multicolumn{2}{|c|}{$\begin{array}{c}\text { Average compressive } \\
\text { strength }\left(\mathrm{N} / \mathrm{mm}^{2}\right)\end{array}$} & $\begin{array}{c}\text { Average tensile } \\
\text { strength }\left(\mathrm{N} / \mathrm{mm}^{2}\right)\end{array}$ \\
\cline { 2 - 4 } & 7 days & 28 days & 28 days \\
\hline MP1 & 30 & 31 & 3.18 \\
\hline MP2 & $\mathbf{3 2}$ & $\mathbf{4 0}$ & $\mathbf{3 . 8 2}$ \\
\hline MP3 & 27.5 & 35 & 2.55 \\
\hline
\end{tabular}

Table 5:For Modified RPC

\begin{tabular}{|c|c|c|c|}
\hline \multirow{2}{*}{ MP } & \multicolumn{2}{|c|}{$\begin{array}{c}\text { Average compressive } \\
\text { strength }\left(\mathrm{N} / \mathrm{mm}^{2}\right)\end{array}$} & $\begin{array}{c}\text { Average tensile } \\
\text { strength }\left(\mathrm{N} / \mathrm{mm}^{2}\right)\end{array}$ \\
\cline { 2 - 4 } & 7 days & 28 days & 28 days \\
\hline MP4 & 32.5 & 37.5 & 4.78 \\
\hline MP5 & 34 & 45 & 5.57 \\
\hline MP6 & 36 & 38 & 6.36 \\
\hline MP7 & 34 & 39 & 6.46 \\
\hline MP8 & $\mathbf{4 0}$ & $\mathbf{4 8}$ & $\mathbf{6 . 5 9}$ \\
\hline MP9 & 38 & 41 & 4.78 \\
\hline MP10 & 36 & 39 & 4.42 \\
\hline MP11 & 38 & 42 & 3.8 \\
\hline MP12 & 34.5 & 38 & 3.6 \\
\hline
\end{tabular}

Hot Water Curing And Hot Water+Normal Curing 
Table 6:For Modified RPC

\begin{tabular}{|c|c|c|}
\hline \multirow[b]{2}{*}{ MP } & \multicolumn{2}{|c|}{ Average compressive strength $\left(\mathrm{N} / \mathrm{mm}^{2}\right)$} \\
\hline & $\begin{array}{l}\text { Hot water curing } \\
\text { (7 days) }\end{array}$ & $\begin{array}{l}\text { Hot water }+ \text { Normal } \\
\text { curing } \\
(7 \text { days }+7 \text { days })\end{array}$ \\
\hline MP4 & 40.5 & 36 \\
\hline MP5 & 42.5 & 39 \\
\hline MP6 & 40 & 42.5 \\
\hline MP7 & 42.6 & 45 \\
\hline MP8 & 45 & 52 \\
\hline MP9 & 35.5 & 45 \\
\hline MP10 & 34 & 43 \\
\hline MP11 & 39 & 40 \\
\hline MP12 & 37 & 36 \\
\hline
\end{tabular}

Table 7: For Optiimum Mix in NRPC and MRPC

\begin{tabular}{|c|c|}
\hline \multirow{2}{*}{ MP } & Average flexural strength $\left(\mathrm{N} / \mathrm{mm}^{2}\right)$ \\
\cline { 2 - 2 } & 7 days \\
\hline MP2 & 6.25 \\
\hline MP8 & 8.25 \\
\hline
\end{tabular}

\section{Results And Discussion}

1) The maximum compressive strength and tensile strength results at 7 days and 28 days for NRPC was MP -2 (because of the $24 \%$ replacement of silica fume by the weight of cement).

2) The maximum compressive strength and tensile strength results at 7 days and 28 days for MRPC was MP - 8(because of the $1.5 \%$ of steel fibre and $0.5 \%$ of polypropylene fibre).

3 ) The addition of silica fume upto $24 \%$ the compressive and tensile strength gets gradually increased.

4) The compressive strength and tensile strength for $1 \%$ and $2 \%$ of steel fibre gives lesser value compared to the $1.5 \%$ steel fibre.

5) The combined curing (hot water and normal water curing) gives the maximum value compared to the normal curing and hot water curing.

\section{Conclusion}

The conclusion from this project were

1) Reactive powder concrete is a concrete without coarse aggregate, possess high compressive, tensile and flexural strength. 2) RPC is used to make a precast concrete element as highway barriers, compound walls of nuclear power plants, etc.

3) Addition of steel fiber and polypropylene fiber in RPC possess additional strength during tension and flexure behavior.

4) For the combined curing (normal curing + hot water curing) results of MRPC, we attain high strength over the other types of curing.

5) Finally, we concluded that RPC with the addition of steel fiber and polypropylene fiber provides high strength when adopt with combined curing.

\section{References}

[1] Aamer Najim, "Experimental study on Reactive Powder and Normal Concrete rectangular beam under different loading rate", 2014.
[2] Anjankumar.M.U, "Reactive Powder Concrete Properties with Cement Replacement Using Waste Material", 2013.

[3] Chandrasekhrareddy.T, "Macro Mechanical Properties of Ultra High Strength Concrete Using River Sand and Silica Fume", 2014.

[4] Deshmukh.A.R, "Comparative Study of Performance and Properties of Reactive Powder Concrete over High Performance Concrete and Conventional Concrete", 2016.

[5] Faizan Akbar, "Optimizing mix proportions for Reactive Powder Concrete and investigating the compressive strength", 2015.

[6] Jaya.L, "A Comparative Study between Reactive Powder Concrete and High Performance Concrete", 2016.

[7] Manasa.G.K, "Study on Properties of Modified Reactive Powder Concrete", 2017.

[8] Maroliya.M.K, "Experimental Investigation on Reactive Powder Concrete containing Steel Fibres and Fly- Ash", 2012.

[9] Nageh Melekaa, "Ultra High Strength Concrete using Economic Materials", 2013.

[10] Pankaj.R, "Reactive Powder Concrete using Fly Ash", (April 2015).

[11] Sumith Kumar.K, "Reactive Powder Concrete with mineral admixtures", 2015.

[12] Sujatha.T, "Modified Reactive Powder Concrete", 2014.

[13] Zia Ur Rahman, "Effect of Polypropylene-Fibres on Compressive and Tensile Strengths of Reactive Powder Concrete", 2016. 